This item was submitted to Loughborough's Research Repository by the author.

Items in Figshare are protected by copyright, with all rights reserved, unless otherwise indicated.

\title{
Performance pedagogy at play: pupils perspectives on primary PE
}

PLEASE CITE THE PUBLISHED VERSION

https://doi.org/10.1080/13573322.2018.1554562

PUBLISHER

(C) Taylor \& Francis (Routledge)

VERSION

AM (Accepted Manuscript)

PUBLISHER STATEMENT

This is an Accepted Manuscript of an article published by Taylor \& Francis in Sport, Education and Society on 4 December 2018, available online: http://www.tandfonline.com/10.1080/13573322.2018.1554562.

\section{LICENCE}

CC BY-NC-ND 4.0

\section{REPOSITORY RECORD}

Stirrup, Julie. 2018. "Performance Pedagogy at Play: Pupils Perspectives on Primary PE". Loughborough University. https://hdl.handle.net/2134/36282. 


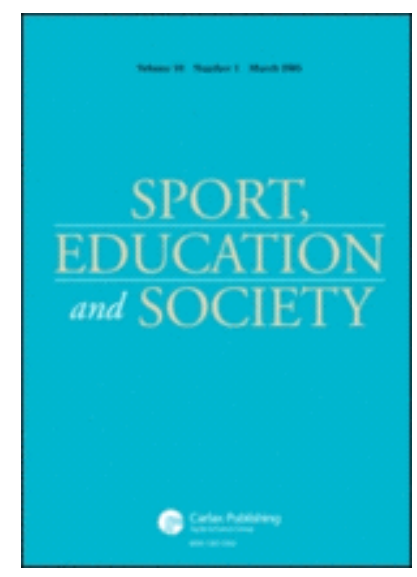

\section{Performance Pedagogy at Play: Pupils perspectives on} primary PE

\begin{tabular}{|r|l|}
\hline Journal: & Sport, Education and Society \\
\hline Manuscript ID & CSES-2018-0199.R2 \\
\hline Manuscript Type: & Original Article \\
\hline Keywords: & physical education, pedagogy, outsourcing, ability, Pedagogic device \\
\hline
\end{tabular}

\section{SCHOLARONE \\ Manuscripts}


Table 1: An overview of the Sports Coach participants

\begin{tabular}{|l|l|l|}
\hline \multicolumn{1}{|c|}{ Sports Coach } & \multicolumn{1}{|c|}{ Experience } & \multicolumn{1}{c|}{ Qualifications } \\
\hline Josh & $\begin{array}{l}\text { Four years working at this } \\
\text { school plus 4 additional years } \\
\text { working for the sports coaching } \\
\text { company across different } \\
\text { schools in the area. }\end{array}$ & $\begin{array}{l}\text { Several level 1s in a variety of } \\
\text { sports including football in } \\
\text { addition to CPD courses put on } \\
\text { by the coaching company e.g. } \\
\text { Dodgeball; Gymnastics }\end{array}$ \\
\hline Orla & $\begin{array}{l}\text { Four years' experience working } \\
\text { at this school plus two years' } \\
\text { experience working at holiday } \\
\text { camps. }\end{array}$ & $\begin{array}{l}\text { Sports Science degree and CPD } \\
\text { courses put on by the coaching } \\
\text { company e.g. Dodgeball; } \\
\text { Gymnastics }\end{array}$ \\
\hline
\end{tabular}

Table 2: Ways of categorising pedagogy - Classification, adopted from Bernstein (1990) and Hoadley, (2006).

\begin{tabular}{|c|c|c|}
\hline \multirow{5}{*}{ 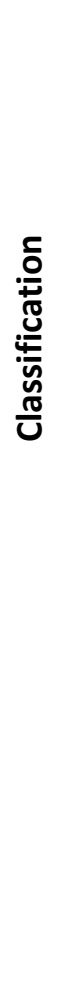 } & \multirow[t]{2}{*}{$\begin{array}{l}\text { Relations between } \\
\text { Discourses }\end{array}$} & $\begin{array}{l}\text { Inter-disciplinary (strength of boundary } \\
\text { between the subject area and other subject } \\
\text { areas) }\end{array}$ \\
\hline & & $\begin{array}{l}\text { Inter - discursive (strength of boundary } \\
\text { between the subject area and everyday } \\
\text { knowledge) }\end{array}$ \\
\hline & \multirow[t]{2}{*}{$\begin{array}{l}\text { Relations between } \\
\text { spaces }\end{array}$} & $\begin{array}{l}\text { Teacher - Child (strength of demarcation } \\
\text { between spaces used by teachers and } \\
\text { learners) }\end{array}$ \\
\hline & & $\begin{array}{l}\text { Space for learning (strength of boundary } \\
\text { between space, internal and external, to } \\
\text { the classroom and learning) }\end{array}$ \\
\hline & $\begin{array}{l}\text { Relations between } \\
\text { agents }\end{array}$ & $\begin{array}{l}\text { Teacher - Child (strength of demarcation } \\
\text { of pedagogic identities) }\end{array}$ \\
\hline
\end{tabular}


Table 3: Recontextualised Knowledge - reproduced from Bernstein (1996, p. 58)

\begin{tabular}{|l|l|l|}
\hline & Competence Models & Performance Models \\
\hline $\begin{array}{c}\text { Categories } \\
\text { Space } \\
\text { Time } \\
\text { Discourses }\end{array}$ & Weakly classified & Strongly classified \\
\hline Evaluation Orientation & Presences & Absences \\
\hline Control & Implicit & Explicit \\
\hline Pedagogic Text & Acquirer & Performance \\
\hline Autonomy & High & Low/High \\
\hline Economy & High cost & Low cost \\
\hline
\end{tabular}


Performance Pedagogy at Play: Pupils perspectives on primary PE

Julie Stirrup School of Sport, Exercise and Health Sciences, Loughborough University, UK Corresponding authors email: j.1.stirrup@,1boro.ac.uk 


\begin{abstract}
Physical education (PE) in England, has historically been and is increasingly seen as a subject in which political agendas can and are being enacted (Penney, 2008) as health, sport and /or leisure agendas compete for space against educational aspirations (Houlihan and Green, 2006). Against this backdrop, in 2012, the UK Government announced the launch of 'Primary PE and Sport Premium' (PPESP) funding (amounting to $£ 450$ million) for English primary schools, initially for three years (although later extended). Drawing on the theoretical work of Basil Bernstein, particularly his concepts, 'pedagogic device' (PD) and 'classification' (c) and 'framing' (f), this paper sets out to explore how, in a neo liberal outsourced world of primary physical education (PPE), pupils construct knowledge of PE. The analyses illustrate how a performance pedagogy appears to dominate the school setting this research took place in. There was a clear focus on sport rather than PE which in turns impacted how pupils saw PE and construct understandings of ability linked to PE, raising questions over the future direction of the subject.
\end{abstract}

Key words: Physical Education, Pedagogy, Outsourcing, Ability, Pedagogic Device 


\section{Introduction}

Physical education (PE) in England, has historically been and is increasingly seen as a subject in which political agendas can and are being enacted (Penney, 2008) as health, sport and /or leisure agendas compete for space against educational aspirations (Houlihan and Green, 2006). Moreover, PE has continued to feel the influence of several stakeholders (including children, parents, teachers, coaches, policy makers, health professionals) as each grapple to influence the direction of the subject. Historically, in education, PE has been seen as a break from 'real' learning or in the words of the Munn Committee Report in Scotland, as a 'noncognitive' subject (Scottish Education Department 1977; Bailey et al, 2009; Griggs and Ward, 2012); viewed instead as a site to promote engagement with physical activity and in turn used to drive and support narrow views on health and issues of obesity and sedentary lifestyles (Tinning, 2012).

Against this backdrop, in 2012, the UK Government announced the launch of 'Primary PE and Sport Premium’ (PPESP) funding (amounting to $£ 450$ million) for English schools, initially for three years (although later extended), to support the improvement of quality PE and sport. A recent report (DfE, research report, 2015) has suggested that the finding has led to an upskilled workforce; equipment to support teaching and learning; additional extracurricular opportunities and; increased participating in inter and intra coemptions. However, indications also suggest that this has altered the way PE is delivered. As Blair and Capel (2011) and Smith (2015) indicate, increasingly, the teaching of PE in England is being undertaken by 'bought in' sports coaches many of whom have National Governing Body (NGB) qualifications but lack educational teaching qualifications and pedagogical skills in relation to planning and assessment specifically (Griggs, 2010). This paper views pedagogy as a way of addressing the 'how' questions relating to the pedagogic message, examining the production, transmission and reproduction of knowledge (see Lusted, 1986). Whilst the coaches within the research are engaging with and enacting pedagogical practices, it is not clear the resources they are drawing on and practices they are utilising. For example, as Cassidy, Jones and Potrac (2016) and Jones (2006) suggest, whilst the value of holistic coaching has been increasingly recognised, it has tended to remain at the level of abstract thought, with many coach education courses still adopting a didactic approach. As such, how do these coaches know and develop pedagogical knowledge for PE? How to differentiate for learners; plan and deliver in line with the aims of the NCPE; assess pupils? Therefore, this 
research paper looks to explore how Primary PE (PPE) funding has impacted on practice within schools and pupils' experiences of PE.

Within the National Curriculum in England, PE is one of the foundation rather than core subjects ${ }^{\mathrm{i}}$ (English, Maths and Science) and therefore, suffers low status relative to that enjoyed by the core subjects (Morgan and Hansen, 2007). As such, several researchers have identified a number of issues regarding teaching and learning within foundation subjects, not least in-service teachers' lack of confidence in delivering them (Armour and Duncombe, 2004; Hallam, Das Gupta and Lee, 2008). Furthermore, it has been argued both within the professional (e.g. Carney and Winkler, 2008) and academic (e.g. Ward and Griggs, 2012) literature that many pupils do not experience PPE in a broad and balanced way, as intended in government policy. For example, the National Curriculum Physical Education (NCPE) provides limited access to Outdoor Adventurous Activity and Athletics (Wright, 2001), rather it is a curriculum dominated by games (Griggs, 2007).

We have existing literature on the impact of outsourcing on who delivers PE (Parnell et al, 2017), the impact of outsourcing on teachers (Smith, 2013) and how schools spend their funding (Griggs, 2016). To date, we have arguments linked to coaches' lack of pedagogical knowledge when delivering curriculum PE (Griggs, 2010) but little is known about the impact of outsourcing on children's understandings of PE as discussed by Sperka and Enright (2017) in their recent scoping review. The aim of this research is therefore to explore how, in a neo liberal outsourced world of PPE, pupils construct knowledge around what PE is. To explore this, I will draw on Basil Bernstein's concepts of the Pedagogic Device (PD) and pedagogic modes (performance and competence). In terms of structure, following this introduction, an exploration of Bernstein's concept, the pedagogic device and how it links to the NCPE at key stage 2 will be discussed. This is followed by an outline of the method used within the project, the participants and how data was analysed. A theoretical discussion of the findings is presented before concluding the key points made.

\section{PD and the reconextualisation of knowledge}

Within Bernstein's code theory, formal educational knowledge is realised through three message systems: i) Curriculum- what counts as valid knowledge; ii) Pedagogy - what counts as the valid transmission of knowledge; and iii) Evaluation - what counts as the valid transmission of this knowledge by the taught. These three messages can be classed as expressions of educational knowledge which is thought to be 'worthwhile'. The concepts 
classification (power) and framing (control) thus lie at the heart of Bernstein's work and alongside the pedagogic device, play a role in the analysis of the research data collected in this study. They will be used to explore how power relations translate through pedagogic discourse to impact pupils understanding of what PE is.

This research focused on how, in a neo liberal outsourced world of primary physical education (PPE), pupils construct knowledge of PE. As such, the pedagogic device became a key concept in understanding what knowledge was created and how it was recontextualised by pupils. The pedagogic device is 'a grammar for producing specialised messages, realizations, a grammar which regulates what it processes: a grammar which orders and positions and yet contains the potential of its own transformation' (Bernstein 1990, 190). It represents the 'voice of pedagogy', establishing the rules, which govern, regulate and define communication and consciousness within education. The PD sets the scene for understanding the sets of rules through which knowledge is converted into classroom talk (Singh, 2002) and transaction. Bernstein conceptualises the PD as a means by which three hierarchically interrelated rules (distribution, recontextualisation and evaluation) create i) categories of legitimation; ii) social relations of order and identity; and iii) the forms through which these are relayed. The PD assists in the explanation of how text (in Bernsteinian terms, communication, verbal and non-verbal) which conveys an informative message within a context, is constituted and transmitted. The distributive rule regulates the distribution of knowledge and relationship between power and social groups. In doing so, it creates boundaries between contexts which become regulated by the distribution of power. The recontextulising rule constructs the social (regulative discourse) and educational discourse (instructional discourse) while the evaluation rule takes these discourses and translates them into pedagogic practice.

The pedagogic device thus makes the transfer of power possible through the distribution and regulation of 'knowledge'; such changes occur as the device and regulation of knowledge conflict with the social field from where the power is derived (Singh, 2002; Bernstein, 2000). Therefore, the education system most commonly becomes a field of cultural reproduction, with the curriculum regulated by what is believed to be most useful to benefit society and the school itself aiming to reproduce the society within which it is located. Within education, the recontextualising principle is active at several levels. Through the official recontextualising field (ORF e.g. NCPE), the state operates at a generic level to legitimise official pedagogic discourse. This discourse is recontextualised through the pedagogic recontextualising field 
(PRF) when the policy is interpreted by teachers/schools and in turn this is further recontextualised when it is 'learnt' by children (Morais and Neves, 2001). In Bernstein's view pedagogic discourse is always an amalgam of 'what' is transmitted (instructional discourse) and 'how' it is transmitted (regulative discourse) the former always and inevitably embedded in the latter. Competing discourses work to become the 'norm' leading to the privileging and codification of certain practices and knowledge.

Within the context of PPE, sports coaches and or teachers are expected to work towards to overarching aims of the National Curriculum Physical Education (NCPE) to ensure that all pupils (DfE, 2013):

-develop competence to excel in a broad range of physical activities

-are physically active for sustained periods of time

•engage in competitive sports and activities

-lead healthy, active lives

Specifically, at Key Stage $2^{\text {ii }}$, coaches and or teachers are expected to share knowledge and evaluate children's development in relation to what they are expected to have acquired as defined by the NCPE KS2 (DfE, 2013):

•use running, jumping, throwing and catching in isolation and in combination -play competitive games, modified where appropriate, and apply basic principles suitable for attacking and defending -develop flexibility, strength, technique, control and balance -perform dances using a range of movement patterns -take part in outdoor and adventurous activity challenges both individually and within a team

- compare their performances with previous ones and demonstrate improvement to achieve their personal best

As evident in the policy text above, PPE is shaped by characteristics of competence, competition, comparison, display and skill and arguably within a context of PE as sport (Hunter, 2004). As such, PE becomes focused on measurable performance, with notions of ability encoded in policy and school recontextualization of this policy. The policy narrative is 
orientated towards assessing and standardising children's performance so by the end of the key stage, 'pupils are expected to know, apply and understand the matters, skills and processes specified in the relevant programme of study' (DfE, NCPE, 2013). The use of criteria (e.g. being able to demonstrate the skill of throwing successfully to get the opponent out in dodgeball) makes children aware of what was considered legitimate knowledge and the means of enacting it within a PE context. Given the narrative of performance discussed above, all pupils are expected to acquire this legitimate knowledge, but different pupils have different access to recognition and realization rules meaning there is the potential for this knowledge to be unequally accessible.

Realisation and recognition rules are the principles which permit distinctions between contexts and lead to the correct production of texts (e.g., language and behaviour) within different contexts. Recognition rules create the means to distinguish between contexts and therefore recognise what constitutes knowledge and context while realisation rules regulate the creation and production of specialised relations within texts. For example, within an PPE context, children may recognise that scoring a goal is valued when playing sport but may not be able to realise how to score in each sport. Recontextulaisation, in Bernstein's theory, is a form of mediation which points to the transformation of knowledge between groups of people, in this research, between sports coaches and pupils in PE. A key aspect is that the social organisations of the school conceal different approaches to knowledge and to the kind of learner that the child is expected to become. These differences result in different pedagogic modes being produced, which Bernstein (1996) referred to as competence and performance modes. These modes have competing notions of the person and the purpose of education. As discussed above, the PD regulates how knowledge is recontextulaised as it moves from outside to inside the school. At the classroom level, social organisation is described in terms of recognition and realisation rules, while the control the teacher exerts over the classroom organisation is related to pedagogic modes. However, children do not simply internalize recognition and realisation rules, rather they reconstruct knowledge according to developing socio- cognitive resources. In other words, children are active in the construction of knowledge, they recontextualise knowledge based on how they interpret the recognition and realisation rules made avalible to them via the pedagogic model adopted in the classroom. How then do sports coaches without any formal training or learning around pedagogy deliver a curriculum which provides equal opportunities for all and does not privilege those who 
perform the 'right' knowledge. Additionally, it becomes important to examine how pupils recontextulise knowledge to construct understandings of PE?

\section{Methodology}

The research reported in this paper is based on semi structured focus group interviews with twenty-four year 3 pupils and semi structured interviews with two sports coaches working at one primary school in the west midlands, England. This school was chosen because the two sports coaches are only contracted to work within this school and therefore are viewed (by pupils and staff) like any other member of staff and given the same level of responsibility (e.g. break and lunchtime duty; detention responsibilities). In contrast, many other sports coaches work across several schools. The school is currently rated as 'good' by Ofsted and is a larger than average size (468 pupils) primary school with almost three quarters of its pupils from disadvantaged backgrounds and receiving support from pupil premium funding (school website).

Year 3 pupils were selected for this research because, this was a small-scale project and the starting point (pilot) for a larger project exploring PE and the transition between primary and secondary school. As such, it was felt that gaining year 3 pupils' perspectives on PE was important since this marks the start of Key Stage 2 and preparation for the transition to secondary school where physical education exists as a compulsory weekly timetabled slot and there are expectations that pupils arrive with specific knowledge of PE.

The twenty-four pupils that participated were selected by the school's PE coordinator. Pupils were selected to ensure there was an equal gender split and mix of pupils who the school identified as being 'sporty' and those they deemed 'less sporty', to get a representative sample of the year group. Prior to any data collection, ethical clearance was obtained from the authors institution ethical committee and signed consent was gained from participants parents. Assent was also obtained from the children themselves prior to the focus groups.

To explore how pupils view PE, it was important to understand how the coaches recontextulaised the curriculum and what they valued in terms of PE. Therefore, semi structured interviews lasting 40 minutes took place with the sports coaches. These interviews centred on adults' perceptions exploring how PPE is taught in the school. The sports coaches had worked in their role at the school for the past four years but are employed by a local sports coaching company. The company provide training and coaching qualifications for their staff in addition to lesson plans based on six-week blocks across various activities, which the 
coaches can then tailor and adapt to meet the needs of their pupils. Furthermore, the coaches undergo an observation of their teaching from the company every 6 months against observation criteria based on Ofsted standards. The table below summaries each coaches experience:

Table 1: An overview of the Sports Coach participants

\section{Inset Table 1 here}

The interview data was transcribed verbatim and analysed using a thematic analysis which, as Roulston (2010) suggests, is one of the most commonly used methods of analysing interview data. First, this process involved reading and re reading the transcripts before a process of coding was used to organise, retrieve and associate fragments of data, thereby enabling the identification of key themes (Miles and Huberman, 1994). These codes 'derived directly from words and phrases uttered by the participant...as well as codes relating to the research questions posed' (Roulston, 2010 p.151). These codes were then complemented by 'analytical' codes generated by reviewing existing literature in the area. For the purposes of this paper, the relevant codes included 'fun', 'specialist', 'games', 'learn', 'good' while the 'analytic' codes incorporated 'training', 'health', 'competition'. Once these codes had been cross checked, they were then 'adjusted, collapsed and revised' (Roulston, 2010, p. 53) into categories of data (e.g., 'teaching and coaching', 'lesson time', 'perceptions of ability').

These categories were organised into thematic groupings or clusters that are used as the basis for explain the data (Roulston, 2010). The following sections of this paper examine the data generated from the focus groups with pupils and interviews with coaches in more detail.

\section{Knowledge transmitted to pupils}

The data illustrates that the sports coaches (Josh and Orla) saw PE and sport as one in the same, furthermore, they (Josh and Orla) suggest that those children who are 'good' at PE, are the ones who could throw furthest or run the fastest and it was these pupils they picked for extracurricular clubs. For them fostering a competitive environment was important because it helped with the school fixtures and competitions:

So pretty much from first thing in the morning until the end of the day, anything that involves sports is me and Orla pretty much, and also taking the kids out for doing extra tournaments and stuff like that, which is pretty busy at the minute. The 
competitions and tournaments are important, we are currently in 4/5 finals in the next two weeks, plus sports day and your girls won the county football, didn't they? (Josh) We have a drop box within our company, which we all have access to, and there are six-week plans for every single sport through every year, which are for every key stage in PE. So which you can just click on either download and print, or you can just look at it on the screen and adapt to what you want, which consists of your learning objective, your success criteria, a warm up, two activities, skilled-based, then turn it into a game situation. We can adapt it and change things so for me, I spend longer on playing and getting pupils competing and involved (Orla)

In utilising Bernstein's concept of classification, the data extracts above are suggestive of a weak classification when exploring how the discourses around sport are moved into the PE classroom. Classification refers to 'the degree of boundary maintenance between contents' (Bernstein, 1973, p. 205). For Bernstein (2000), dominant power relations establish boundaries between categories, therefore, classification announces the relations between categories, whether that is between agencies, agents, discourses or practices. As the data below illustrates, a weak boundary between sport and PE may have consequences for how the subject is understood.

Table 2: Ways of categorising pedagogy - Classification, adopted from Bernstein (1990) and Hoadley, (2006).

\section{Inset Table 2 here}

Between different categories there may be social divisions of labour and of discourse (Bernstein, 2000). If these discourses are specialised differently they develop a 'space' between themselves, each having a unique voice and identity (for example, school subjects). Central to classification, therefore, is the space (or insulation) created between these categories. Focus on boundary strength enables the structure of the curriculum (and the meanings derived from such 'ordering of relationships') to be analysed. Strong classification $(\mathrm{C}+)$ occurs when contents (e.g., areas of knowledge or subject disciplines) are well insulated from each other with strong boundaries; in contrast, weak classification (C-) is depicted by a reduction in insulation between contents and a blurring of the boundaries.

In the context of this school, the data suggests that within the school structure, in terms of PE lessons and extracurricular clubs, there is a weak classification (C-) between the discourses of 
sport and PE. PE and sport are seen as one in the same with discourses of competition, tournaments and games used when discussing how PE lessons were planned and the coaches' role within the school. This C- between PE and sport discourse is reflected in the work of others, as discussed later in this paper. This particular school setting evidently values competition and sport, which in turn influences the knowledge recontextualised within lessons and sports coaches' perceptions of what the 'able' child should look like in situ. Specifically, in this context, all lessons and the curriculum enacted the school is driven by the company:

Our company put out a template or put out what they think and then the school (PE co-ordinator and deputy head ${ }^{i i i}$ ) just say, yes, that sounds about right. Or, we're not too sure about that. But at the start of every year, the school will have a look at the short term and the long-term plan the company put together, and then we dictate or decide what we want them to learn, and then everyone gives it the go ahead, and then that's what happens. (Josh)

This data is illustrative of the various stakeholders who influence PE but also of how narratives of what pupils need in PE, are recontextulaised under the influence of these stakeholders (sports coach companies) who potentially conflate sport and PE, with 'able' pupils singled out for extracurricular and school teams:

I spend longer on playing and getting pupils competing and involved (Orla)

Our kids we take to the competitions are the ones who enjoy PE and do well in it. They aren't always the best-behaved kids, but they can play sport (Josh)

The focus on 'competition' and 'playing sport' (illustrated in the empirical data so far) is suggestive of a performance based instructional discourse which has dominated UK secondary schools over recent years through the publication of exam results, league tables and OFSTED inspections but is now also evident in the early years and primary school education (Rogers and Lapping, 2012). The transformation of discourse into practice Bernstein (2000) argues is the central to the pedagogisation of knowledge and can be understood as a series of transformations starting at an abstract level and moving in steps towards practice. His account of the transformation of discourse into practice identifies two contrasting pedagogic models that flow from the different conceptualisations at each stage of the transformation; a Competence model and a Performance model. Table 3 summarises the features of each model. 
Inset Table 3 here

A Competence model is characterised by an emphasis on the realisation of competencies. It has a learner-centred orientation to the context and content of learning. It focuses on what is present in a child's learning, and there is the expectation of multiple texts as representations of learning. It therefore requires a high level of personalisation in the criteria for evaluation. In this model professional autonomy is high, and professionalism inheres in 'reading the text' that the child produces. A Performance model as placing emphasis upon, 'a specific output of the acquirer, upon a particular text the acquirer is expected to construct, and upon the specialised skills necessary to the production of this specific output, text or product' (Bernstein, 2000, p.44).

A Performance model is closely aligned with the current dominant discourse in education. It is evident in current political rhetoric and policy, across all phases of schooling, in the emphasis on the acquisition of pre-determined knowledge and skills that are closely managed and assessed against explicit criteria. Pedagogically, this is apparent in strong control over who does what, when and how. Knowledge is recontextulaised with a performance pedagogic mode as the data illustrates, children sat in the same place at the start of each lesson, followed the same routine and were expected to follow rules. Rather than producing original work, children followed drills and replicated the skills demonstrated by the teacher:

[In PE] We sit down, and we look at all the equipment, and them Mr Jones tell us what we're going to do. And we have to find a space to stand, and then Mr Jones is going to put us in groups. (Oliver)

We start playing. Stuck in the mud and stuff. That's our warm-up game, and then. We'll start doing throwing. Then we get into the real PE sessions. We start throwing and catching. (Gurj)

Then its break. After break time, if we're lucky we'll get to play dodgeball or Tails. If we're not cheeky. (Kadeem)

In contrast, a Competence model aligns with an alternative discourse. The emphasis is on a fluid response to children as individuals, starting from what they currently know and can do, and is focused on learning as a shared, socially constructed endeavour (Bernstein, 2000).

Currently, the ideological roots of PPE and the discursive links between PE and sport represent an intersection of two distinctly different discourses and the resulting pedagogical 
expectations at the level of practice are difficult to merge. PPE and sport within the dominant discourse illustrated in the coaches' data, results in a Performance pedagogical model which focuses learning in terms of physical activity, competition, health and life long participation. Knowledge and skills are therefore, acquired in preparation for what comes in secondary school and beyond. This learning focus was suggested further through pupils' focus group data. When asked to discuss how they would describe PE, pupils responded with:

Fun, exercise, healthy (Dermott)

Competing, exercise, friends (Mia)

Good for me, exciting, sports $(\mathrm{Cal})$

A Competence pedagogical model in contrast is predicated on a child as an individual, a child whose learning is understood to take place within a specific context and specific relationships. There is, therefore, an expectation that learning may take different pathways and occur within different time frames. The data collected from these sports coaches, suggests a Performance pedagogical model is currently at play with the concept of sport and competition surpassing any other learning which can take place through PE, in a sense focusing solely on the physical rather than the development of the whole child. These coaches recognised that they do not plan their own lessons and had little formal training in relation to 'teaching' PE, instead drawing on their own experiences of being coached at sport and completing Level 1 NGB qualifications. They are given lesson plans created by their sports company in line with NCPE to deliver across week blocks with criteria linked to what is expected of pupils again in line with policy. There was no sense of meeting the individual's needs. As illustrated in the data above, pupils suggest that they all did the same in lessons, that 'real pe' was displaying the core skills in a game context and that there was a self and peer awareness of what was absent from pupils in PE. For example, there is a link created in lessons and recontextulaised through Gurj at least that 'real pe' requires displaying core skills (throwing and catching). Moreover, Abu illustrates pupils' awareness of evaluation criteria and what pupils have not yet acquired:

If you have a friend which doesn't really do sports, you can teach them how to do sports after PE coz sometimes they won't do PE coz they aren't very good and no one wants them on their team (Abu) 
Furthermore, the weak classification between PE and sport, raises further questions over the pedagogical model in place and the impact of this for the learner. Is competition valued in the schools PE lessons because they are delivered by sports coaches and not teachers? Previous research (Griggs, 2010) has illustrated how sports coaches lack of pedagogical knowledge is potentially problematic. Furthermore, if the NCPE is recontextualised to prioritise competition in this setting, how do pupils construct their understanding of PE?

\section{Sports Coaches not PE Teachers}

Outsourcing external provision for PPE is not something confined either to primary schools or the UK, rather it is becoming an increasingly regular occurrence within education internationally (Sperka and Enright, 2017). Davis-Blake and Broschak (2009) have argued, outsourcing is a multidimensional practice that varies in its complexity on the basis of: the range of goods and services outsourced; the amount of control exercised by an outsourcer over a supplier; the embeddedness of the social relationship between outsourcer and supplier; and, the level of formality governing the outsourcing arrangement. The effects of outsourcing and privatisation on education varies depending on context and subject, but as Macdonald (2014, p. 496) argues, discourses of 'markets, opportunity, choice and competition' are 'very seductive for all those with interests in PE'. Within the UK contexts there has been an increasing concern over privatisation and outsourcing (e.g. Evans and Davies, 2014; Williams and Macdonald, 2015). In the UK primary school context, this is particularly pertinent given the increased funding provided by government and accountability given to the school for the spending of PPESP money. Several authors have addressed issues around outsourcing PE (Griggs, 2008; Blair and Capel, 2011; Jones and Green, 2017) and the purpose of my paper is not to recover this terrain specifically. Rather it is to explore how in a neo liberal, outsourced world of PPE, how pupils construct knowledge around what PE is.

The data collected is illustrative of pupils seeing PE as sport. Many of the pupils when asked what they did in PE listed various sports rather than recognising PE as anything other than sport:

We do lots of different sport like throwing, catching, dodgeball (Rosie)

Sometimes we work in groups and play sport and do training, we do running and jumping (Liam)

We play lots of games, I like that we play games and win (Sophie) 
Furthermore, when asked what they enjoyed about PE, the clear majority highlighted the competitive element of games:

We race in PE and I like it. I like winning. When we do Javelin I always throw the furthest too (Darragh)

Its fun but only when we win in games (Lucy)

We play Tails and Dodgeball and if we're good we get to play games in teams (Conor)

These data extracts are representative of the responses received from all twenty-four pupils and in themselves, raise further questions about how and why the children see PE linked to sport and competition. It is because the dominant ideology of PE within the school is sport rather than PE? The discussion below looks to explore some of the issues associated with the boundary between PE as competitive sport and PE as something other than competitive sport.

The language and actions of sport are enduring historical features of PPE in both the UK (Jess, McEvilly and Corse, 2016) and internationally. Specifically, within England, PE discourses have focused on national sporting success and combatting obesity and sedentary lifestyles (Griggs, 2016; Petrie and Clarkin - Philips, 2016). As Kirk (2001) suggests, what we value in PE and what has become the subject matter for PE is arguably sport. In his memetic perspectives on PE, Tinning (2012) supports both discourses, suggesting that PE is dominated with the 'obesity/exercise' memplex and argues that the old memes such as a philosophical argument for value of PA as an educational activity are perhaps not the future of PE. PPE has been identified as a key age for children to learn movement skills and this has dated back to the early 20 th century with Swedish gymnastics dominating the PE curriculum (Kirk, 2010). Looking at PPE today, there is a tendency to associate it with fundamental movement skills (FMS) which some would argue is a reductionist approach to PE because FMS normalises human actions into certain ways of moving and ignores human materialities of learning (Ward, 2017). In other words, such an approach does not necessarily recognise the individual learner/child. Within a neo liberal education context then, the brought in services of sports coaches can often reinforce the narrow ways children come to understand themselves and others, seeing PE as these rather reductionist practices of sport (Evans 2014; Smith 2013). This idea of a narrow view of PE is echoed in the data: 
So pretty much me and Orla do anything that's sport-related from breakfast club where the kids can come, eat and play sport to lessons to after school sports clubs (Josh)

In PE we just play lots of sport and do competitions, until someone cries then we have to stop (Lauren)

PE is fun coz we can run around and just play sport, we don't have to do work (Kadeem)

Furthermore, the pupils themselves stared to make clear links between ability, peers perception and how they felt about PE:

I like PE but not playing football or throwing Javelin, I can't do that (Sarah)

If we are good we get to do play for the team and people pass to us in the games (Finn)

\section{Pupils construction of $P E$ and ability}

As Evans (2004) and others (Evans and Penney, 2008; Hay and lisahunter, 2006; Hay and Macdonald, 2010; Wright and Burrows, 2006) suggest, 'ability' tends to be categorised as a simplistic entity. While this has centred attention on the nature of individual decision-making in PE, health and sport, it has little to say about the nature of 'ability' as a dynamic, sociocultural construct and process. Education is defined only in relation to the values and ideals that succeed in schools and other social fields, when consideration should be given to the ways in which 'abilities' are configured, recognized, nurtured and rejected within and across the physical cultures of communities and schools. In this specific school context and in line with NCPE ability was structured by sports coaches and pupils in relation to what the pupils did not have, what they could not do. In this way pupils were evaluated in relation to explicit criteria of what they could not do, not only by the coaches but also by their peers. The school constitutes a process whereby rules for communication and acquisition of school knowledge regulate consciousness in the classroom, and by extension, legitimate specific identities within pedagogic discourse (the sum of communication and acquisition of knowledge at the PE lesson level).The PD can then be used to explore and explain how knowledge (official or local) converted into pedagogic communication acts upon the potential meanings made available for transmission and acquisition (Singh, 2002). As we see in the 
data, several pupils mentioned how if they were not see as 'good' defined as able to do well in the game then they were not successful in lessons or school sport.

We do competitions and sometimes people cry if they aren't very good. They still have to do it but some of them cry. Not me though I like the competitions like throwing (Lauren)

Its important when we pick teams it's from those who enjoy sport and show that they are good at it. We tend to pick the same kids who are good allrounders (Orla)

Previous research focused on performance pedagogical models, ability and secondary school have highlighted that ability is often linked to embodiment within PE in terms of displaying the right body shape (Evans and Penney 2008; Wright and Burrows, 2006). However, this data suggests that being able in this context is about demonstrating the correct sporting competence and competing, displaying these characteristics is valued by both the sports coaches and peers.

\section{Discussion}

This paper has set out to explore, how in a neo liberal, outsourced world of PPE, pupils construct knowledge around what PE is. In doing so it has highlighted the performance pedagogy that appears to dominate this particular school setting and the focus on sport rather than PE which in turns impacts how pupils see PE and construct understandings of ability linked to PE. Pupils via the recognition and realisation rules afforded within the classroom by the coaches, constructed their knowledge around PE. The data presented illustrates that what was valued and seen as 'legitimate' knowledge in the school, was sport. Pupils felt judged and in turn judged others on their ability to perform and play sport well. Furthermore, pupils constructions of PE as sport, is reinforced by the coach data and how they view both PE and their role within PE - ideas of 'playing', 'competing' and 'sport' is echoed in their data.

The dominance of sport in PPE is something previous research has echoed with others offering alternatives to the sports focused curriculum, e.g. movement culture (Ward and Quennerstedt, 2015) and physical literacy (Whitehead, 2007). This data suggests that it is perhaps the physical development in line with sport which is surpassing the other aspects PPE can offer children/learners. At the level of policy rhetoric, there is some reference to the development of the whole child with a focus on developing health, movement and skills but how this is recontextulaised and implemented within schools appears to foster a performance 
pedagogy which reduces the importance of the individuals needs and judges' learners against performance criteria, often in a competitive environment.

Recognising the limitations of this paper and the scope for further work around pupils' construction of knowledge within $\mathrm{PE}$, for the author this paper perhaps raises more questions than it answers. If advocating for a PPE curriculum which is culturally responsive and contextually relevant for its learners, then do we need to question whose needs are being met by our current PPE practice? Furthermore, do our current practices focus on learning or simply sports which are assessed against performance criteria (as is suggested in this research to some extent) and to this end do we need to look for alternative discourses within PPE which allow for a competence pedagogical model? 
References

Armour, K. M., and R. Duncombe. (2004). Teachers' Continuing Professional Development in Primary Physical Education: Lessons from Present and Past to Inform the Future. Physical Education and Sport Pedagogy 9 (1): 3-21.

Bailey, R., K. Armour, D. Kirk, M. Jess, I. Pickup, R. Sandford, and BERA Physical Education and Sport Pedagogy Special Interest Group. (2009). The educational benefits claimed for physical education and school sport: An academic review. Research Papers in Education 24 (1): 1-27.

Bernstein, B., (1973). A brief account of the theory of codes, in Class, Codes and Control, vol1, Routledge and Kegan Paul (revised edition- 1974).

Bernstein, B., (1990). Class, codes and control, vol. 4: the structuring of pedagogic discourse. London: Routledge.

Bernstein, B., (1996). Pedagogy, symbolic control and identity: theory, research, critique. London: Taylor and Francis.

Bernstein, B., (2000). Pedagogy, symbolic control and identity: theory, research and critique (revised edn), London: Rowman and Littlefield.

Blair, R., and S. Capel. (2011). Primary physical education, coaches and continuing professional development. Sport, Education and Society 16 (4): 485-505

Burrows, L., (2017). Children as change agents for family health, Health Education, 117 (5): 498-510.

Charmaz, K. (2000). Grounded theory: Objectivist and subjectivist methods. In N. K. Denzin and Y. S. Lincoln (Eds.), Handbook of qualitative research (2nd ed., pp. 509-535). Thousand Oaks, CA: Sage.

Cheminais, R. (2008) Engaging Pupil Voice to Ensure That Every Child Matters: A Practical Guide. London: Fulton

Cope, E., R. Bailey, and D. Parnell. (2015). Outsourcing Physical Education: A Critical Discussion. International Journal of Physical Education 52 (4): 2-11. 
Davis-Blake, A. and Broschak, J. P. (2009). Outsourcing and the changing nature of work. Annual Review of Sociology, 35 (32): 1-40

DfE, (2013) https://www.gov.uk/government/publications/national-curriculum-in-englandphysical-education-programmes-of-study

DfE, (2015) The PE and sport premium: an investigation in primary schools Research report avalible at https://www.gov.uk/government/publications/pe-and-sport-premium-aninvestigation-in-primary-schools

Evans, J., (2004). Making a Difference? Education and Ability in Physical Education European Physical Education Review, 10 (1): 95 - 108

Evans, J., and D. Penney. (2008). Levels on the Playing Field: The Social Construction of Physical 'Ability' in the Physical Education Curriculum. Physical Education and Sport Pedagogy 13 (1): 31-47

Evans, J., and B. Davies. (2014). Physical Education PLC: Neoliberalism, Curriculum and Governance. New Directions for PESP Research. Sport, Education and Society 19 (7): 869884.

Evans, J. (2014). Equity and inclusion in physical education PLC. European Physical Education Review, 20 (3): 319 - 334

Griggs, G. (2007). Physical Education: Primary Matters, Secondary Importance. Education 31335 (1): 59-69.

Griggs, G. (2008). Outsiders inside: The use of sports coaches in primary schools in the West Midlands. Physical Education Matters, 3(2): 33-36.

Griggs, G. (2010). For Sale - Primary Physical Education. £20 per Hour or Nearest Offer. Education 3-13 38(1): 39-46.

Griggs, G., and Ward, G. (2012). Physical Education in the UK: disconnections and reconnections, Curriculum Journal, 23 (2): 207-229

Griggs, G. (2016). Spending the Primary Physical Education and Sport Premium: A West Midlands Case Study. Education 3 -13 44 (5): 547-555. 
Hallam, J., M. Das Gupta, and H. Lee. (2008). An Exploration of Primary School Teachers' Understanding of Art and the Place of Art in the Primary School Curriculum. Curriculum Journal 19 (4): 269-281.

Hay, P., and Lisahunter, (2006). Please Mr Hay, what are my poss(abilities)?': legitimation of ability through physical education practices Sport Education and Society 11 (3): 293 - 310 Hay, P.J. and Macdonald, D., (2010). Evidence for the social construction of ability in physical education. Sport, education and society, 15 (1): 1-18.10

Houlihan, B., and M. Green. (2006). The changing status of school sport and physical education: Explaining policy change. Sport, Education and Society 11 (1): 73-92.

Hunter, L. (2004) Bourdieu and the social space of the PE class: reproduction of doxa through practice, Sport, Education and Society, 9(2): 175-193.

Jess, M., McEvilly, N., and Carse, N., (2016). Moving primary physical education forward: start at the beginning, Education 3-13 i-first article

Jones, L. and Green, K. (2017) Who teaches primary physical education? Change and transformation through the eyes of subject leaders, 22 (6): 759-771

Kirk D., (2001). Schooling bodies through physical education: Insights from social epistemology and curriculum history. Studies in Philosophy and Education, 20: 475-487

Kirk, D., (2010). Physical education futures, London: Routledge

Lair, C. D. (2012). Outsourcing and the Contracting of Responsibility. Sociological Inquiry 82 (4): 557-577

Long J., and Carless, D., (2010), Hearing, Listening and Acting. In Mary O’Sullivan and Ann MacPhail (Ed). Young people's voices in physical education and youth sport. London: Routhledge

Macdonald, D. (2014). Is Global Neo-liberalism Shaping the Future of Physical Education? Physical Education and Sport Pedagogy 19 (5): 494-499

MacPhail, A., and Kinchin, G. (2004). The use of drawings as an evaluative tool: Students' experiences of sport education. Physical Education \& Sport Pedagogy, 9(1): 87-108

Mannay, D. (2016). Visual, narrative and creative methods: Application, reflection and ethics. London: Routledge. 
Morais, A. and Neves, I., (2001). 'Pedagogic social contexts: studies for a sociology of learning'. In Morais, A., Neves, I., Davies, B., and Daniels, H., (2001) (Eds), Towards a Sociology of Pedagogy: the contribution of Basil Bernstein to research, New York: Peter Lang.

Morgan PJ, and Hansen V., (2007). Recommendations to improve primary school PE: The classroom teacher's perspective. Journal of Educational Research, 101(2): 99-112

Miles, M. B., and Huberman, A. M. (1994). Qualitative data analysis: An expanded sourcebook (2nd ed.). Thousand Oaks, CA: Sage.

Parnell, D., Cope, E., Bailey, R. and Widdop, P. (2017). Sport policy and English primary physical education: the role of professional football clubs in outsourcing, Sport in Society, 20(2): 292-302

Penney, D. (2008). Playing a political game and playing for position: Policy and curriculum development in health and PE. European Physical Education Review 4 (1): 33-49.

Petrie, K., and Clarkin- Phillips, J., (2017). 'Physical Education' in early childhood education: Implications for primary school curricula, European Physical Education Review, 1 (17): $2-17$

Roulston, J. (2010). Reflective interviewing. London: Sage.

Rogers, S. and Lapping, C. (2012). Recontextualising 'Play' in Early Years Pedagogy: Competence, Performance and Excess in Policy and Practice, British Journal of Educational Studies 60 (3): 243-260

Sharpe, P. A., Greaney, M. L., Royce, S., and Fields, R. (2004). Children's drawings of physical activity: Implications for needs assessment and programming. Journal of Physical Education, Recreation and Dance, 75(3): 27-32.

Singh, P., (2002). Pedagogising Knowledge: Bernstein's theory of the pedagogic device, British Journal of Sociology of Education, 23(4):571-582

Smith, A. (2015). Primary school physical education and sports coaches: evidence from a study of School Sport Partnerships in north-west England, Sport, Education and Society, 20 (7): $872-888$ 
Sperka, L., and E. Enright. (2017). The Outsourcing of Health and Physical Education. European Physical Education Review. Online

Tinning, R., (2012). The idea of physical education: A metric perspective. Physical Education and Sport Pedagogy, 17 (2): 115-126

Ward, G., and Quennerstedt, M. (2015). Knowing in primary physical education in the UK: Negotiating movement culture. Sport, Education and Society 20 (5): 588 - 603

Ward, G., (2017) Moving beyond sport in primary physical education. In Griggs, G., and Petrie, K., (2017) (Eds) Routledge Handbook of Primary Physical Education, London: Routledge

Whitehead, M., (2007) Physical literacy: Philosophical considerations in relation to developing a sense of self universality and propositional knowledge. Sport, Ethics and Philosophy 1: 281 - 298

Williams, B. J., and D. Macdonald. (2015). Explaining Outsourcing in Health, Sport and Physical Education. Sport, Education and Society 20 (1): 57-72

Wright, J., and Burrows, L., (2006). Re-conceiving ability in physical education: a social analysis, Sport, Education and Society 11 (3): 275 -291

Wright, L. (2001). Rescuing Primary Physical Education and Saving those Values that Matter Most. British Journal of Teaching Physical Education 33 (1): 37-39.

\footnotetext{
i The National Curriculum n England, is organised based on 4 key stages and 12 subjects, classified in legal terms as 'core' and 'other foundation' subjects. Pupils must study core subjects (English, Math, Science) and have the statutory entitlement to be able to study the foundation subjects beyond Key stage 3 .

ii Key Stage 2 refers to the four years of schooling in maintained schools in England and Wales normally known as Year 3, Year 4, Year 5 and Year 6, when the pupils are aged between 7 and 11 years.

iii Josh and Orla both mentioned in their interviews that the PE co-ordinator and Deputy Head Teacher made the final decisions on the curriculum, how funding is spent, the tournaments the school enters and how sports day is run within the school.
} 